\title{
Can genocide, crimes against humanity and war crimes be pardoned or amnestied?
}

\author{
by Anees Ahmed and Merryn Quayle
}

This article is based on a lecture made on the same topic at the Institute of Advanced Legal Studies on January 28, 2008.

\section{INTRODUCTION}

With the commencement of the first trial at the Khmer Rouge Tribunal ("KRT"), attention has once again been focused on the crimes committed by the Khmer Rouge and the likelihood of successful prosecution of those most responsible for those crimes.

Ieng Sary, a senior figure in the Khmer Rouge, has been charged by the KRT prosecutors with committing genocide, crimes against humanity and war crimes. He was the Deputy Prime Minister and Foreign Minister of Democratic Kampuchea from 1975 to 1979 and held several senior positions in the Khmer Rouge until his defection in 1996. His lawyers have argued that an amnesty and pardon granted to him by the King of Cambodia in 1996 effectively immunise him from prosecution by the KRT.

This paper will focus on issues pertaining to the validity and applicability of an amnesty or a pardon granted to a perpetrator who has committed serious international crimes such as genocide, crimes against humanity and war crimes. The authors will argue that neither pardon nor amnesty can absolve serious violations of international criminal law (see Leila Nadya Sadat, "Exile, Amnesty and International Law", 81 Notre Dame Law Review 955 (2006) ("Sadat"), p 957). There is a "crystallising international norm" against impunity which denies the legal possibility of pardon or amnesty for serious international crimes (Kallon v Kamara, case no SCSL-2004-15-AR72(E), SCSL2004-16-AR72(E), decision on challenge to jurisdiction: Lome Accord Amnesty, March 13, 2004 ("Kallon decision"), para 82). Due to the grave nature of these crimes, and their jus cogens status in international law as fundamental principles from which no derogation is permitted, an amnesty or pardon purporting to immunise perpetrators of such crimes cannot be upheld under international law, and should not bind international or domestic courts trying offences of this nature.

\section{FACTUAL BACKGROUND: PROSECUTING AN "AMNESTIED" PERSON AT THE KRT}

After overthrowing the Khmer Rouge's Democratic Kampuchea regime on January 7, 1979, the Government of the People's Republic of Kampuchea established the People's Revolutionary Tribunal ("PRT") to "try the acts of genocide committed by the Pol Pot-Ieng Sary clique." The PRT indicted, prosecuted and convicted Pol Pot and Ieng Sary in their absence of "genocide", sentenced them to death and ordered the confiscation of their property. They never served their sentences.

On July 15, 1994, the Government of Cambodia enacted an "Outlawing Law" which made it a crime to be a member of the Khmer Rouge. Specifically, the Outlawing Law outlawed being a member of the "political organisation or the military forces of the Democratic Kampuchea Group”. This Outlawing Law also empowered the King of Cambodia to grant an amnesty or pardon to those who violated it. When Ieng Sary defected from the Khmer Rouge in 1996, the King granted him a pardon for his PRT conviction and an amnesty from any future prosecution under the Outlawing Law.

On October 27, 2004, following agreement between the United Nations and the Government of Cambodia, the KRT was established to prosecute crimes committed by the Khmer Rouge during the period of Democratic Kampuchea from 1975 to 1979 ("Agreement")). The law governing the KRT ("KRT Law") provides that the scope of any amnesty or pardon granted to an accused person prior to the creation of the KRT is a matter to be decided by that tribunal.

Ieng Sary was arrested on November 12, 2007 pursuant to an arrest warrant from the KRT. He is charged with committing acts which may be legally classified as genocide, crimes against humanity and grave breaches of the Geneva Conventions of August 12, 1949. In proceedings in October 2008 before the Pre-Trial Chamber of the KRT, that chamber was faced with the issue of whether, as Ieng Sary's lawyers alleged, the royal 
amnesty and pardon of 1996 are binding on the KRT such that they prohibit Ieng Sary from being prosecuted by the KRT for the above-mentioned offences.

The KRT's prosecutors contended that the amnesty and pardon did not immunise Ieng Sary from being tried before the KRT because, amongst other reasons, assuming that the royal pardon was issued in relation to the same crimes for which Ieng Sary is currently being charged before the KRT, such pardon is not valid for these crimes as they have a jus cogens status in international law. Even if the pardon is deemed valid, the KRT, being a special internationalised tribunal, is not bound by national pardons or amnesties. In its decision, the Pre-Trial Chamber of the KRT? without striking down the amnesty or pardon or laying down a general rule on their legality ? ruled that the application of the amnesty on Ieng Sary's current prosecution is "uncertain" and it is not "manifest or evident" that the amnesty/pardon will prevent his conviction on genocide. The Pre-Trial Chamber reached this conclusion by considering that at the time the amnesty was issued, the death penalty had been abolished in Cambodia and, in any event, the language of the amnesty was "inconsistent", both in itself and with the provision in the Constitution of Cambodia that permits the King to grant amnesties and pardons.

Against this background, the argument that genocide, crimes against humanity and war crimes cannot be pardoned or amnestied, with particular reference to Ieng Sary's case in the KRT, will be discussed in the remainder of this paper.

\section{AMNESTIES AND PARDONS ARE NOT A BAR TO PROSECUTION OF SERIOUS INTERNATIONAL CRIMES}

\section{Trading justice for peace? The increasing unacceptability of amnesties and pardons for serious international crimes}

Amnesty and pardon have been "the prerogative of power from time immemorial" (Prosecutor v Kondewa, case no SCSL-2004-14-AR72(E), Decision on Lack of Jurisdiction / Abuse of Process: Amnesty Provided by Lome Accord, separate opinion of Justice Geoffrey Robertson, Appeals Chamber, May 25, 2004 ("Kondewa decision”), para 15). Amnesty usually refers to the act of a sovereign granting immunity from criminal prosecutions to a person or a group for past criminal acts. A pardon, on the other hand, is granted after a person is prosecuted and found guilty of an offence by a court. Amnesty is the abolition and forgetfulness of the offence; pardon is forgiveness. However, despite these differences, the two acts are arguably legally indistinct. They have the same operative legal effect in one important way: both shield a person from criminal punishment or civil liability (Black's Law Dictionary, eighth ed, 2004, "Amnesty"). Consequently, amnesty and pardons may be referred to interchangeably. An amnesty, however, prevents a court from going through the process of discovering the truth about the crime/s through a trial; see Diane Orenlichter, "Settling Accounts: the Duty to Prosecute Human Rights Violations of a Prior Regime”, 100 Yale Law Journal 2537, 2604 (1991).

In the context of a state's obligation under international law to bring to justice those who bear responsibility for international crimes, both amnesties and pardons may be viewed as running counter to this obligation. In re List and Others the US Military Tribunal at Nuremberg defined an international crime as: "such act universally recognised as criminal, which is considered a grave matter of international concern and for some valid reason cannot be left within the exclusive jurisdiction of the State that would have control over it under ordinary circumstances" (Kittichaisare, International Criminal Law (Oxford, 2001), p 3 in Kallon decision, para 68). This issue? whether courts and tribunals are bound by amnesties and pardons bestowed on perpetrators responsible for crimes so appalling that they are categorised as being "against humanity"? has become increasingly important in international human rights law. There is much debate surrounding the modern use of amnesties and pardons, which may be employed by a state to save lives in the short term ? for example, by ending a war ? at the expense of injustice in the long term to the victims of those amnestied (see Kondewa decision, paras 15-25).

Conventional wisdom holds that the morality and practicality of the "justice for peace" trade-off is a sufficient argument in favour of amnesties (Sadat, p 955). This wisdom is, however, being increasingly challenged. There has been a change in the international community's approach to amnesty "from regarding it as the blessing of forgiveness to reproaching it as the curse of impunity" in the words of Geoffrey Robertson QC, in Crimes Against Humanity: The Struggle for Global Justice, third ed, (2006) p 304. The image of defiant leaders, credibly accused of some of the worst human rights violations imaginable, "living happily ever after, thanks to an amnesty" is socially, politically and legally unpalatable. Recent experience also indicates that warlords and political leaders committing human rights atrocities "are not deterred by the amnesties obtained, but rather emboldened (Sadat, p 966)." The situations in the former Yugoslavia and Sierra Leone suggest that amnesty deals, instead of resulting in peace, may in fact assist in the creation of an impunity culture in which violence becomes the norm, rather than the exception.

The United Nations Secretary General stated in his 2000 report on the establishment of the Special Court of Sierra Leone ("SCSL") that:

"While recognising that amnesty is an accepted legal concept and a gesture of peace and reconciliation at the end of a civil war or an internal armed conflict, [...] amnesty cannot be granted in respect of international crimes, such as genocide, crimes against humanity or other serious violations of international humanitarian law (United Nations Secretary- 
General, Report of the Secretary-General on the Establishment of Special Court for Sierra Leone, UN Doc S/2000/915, October 4, 2000, p 22).”

Similarly, international law reflects the growing realisation of the unacceptability of granting amnesties and pardons for serious violations of international humanitarian law that are so repugnant that no circumstances can justify them. As the KRT Prosecutors argued in the Ieng Sary case, international law and practice has developed to regard amnesties given to those most to blame for these types of crimes not only what was described as an "enormous indulgence" in the Kondewa decision, but an indulgence that must not be upheld by law. Immunity, even in the face of a pardon or amnesty, must not be given to those responsible for the most serious violations of international criminal law.

\section{International crimes are a concern of all humanity}

The gravity and scale of crimes that "shock the conscience of humanity", even if committed within the borders of a single state and primarily against nationals of that state, can make these crimes a concern of the whole international community (reference taken from the Rome Statute of the International Criminal Court, July 1, 2002, $2^{\text {nd }}$ recital of the preamble). The characterisation by the Security Council of certain crimes as "threat to peace" or "breach of peace", ipso jure has the effect of making the conflict a concern of the international community. Similarly, crimes like genocide, even if committed against a group within one country, are a concern for all humanity. In other words, although some crimes may have occurred within a state's territory, they "defy boundaries in a very real way: cases which by their magnitude, so threaten our sense of humanity that they belong to a sort of 'world heritage of pain'” (see Mégert, F, "In Defence of Hybridity: Towards a Representational Theory of International Criminal Justice", Cornell International Law Journal, Fall 2005, p 737). In Kambanda, the International Criminal Tribunal for Rwanda ("ICTR") recognised that "genocide has inflicted great losses on humanity" and reiterated the "need for international cooperation to liberate humanity from this scourge".

\section{The jus cogens status of serious international crimes}

Certain international crimes may be categorised as jus cogens, ("compelling law"). Jus cogens is a fundamental principle of international law which is accepted by the international community as a rule from which no derogation is permitted. When a crime has jus cogens status it becomes, in international law vernacular, "a peremptory norm from which no derogation is permitted" (see Ruling on Israeli Security Wall, International Court of Justice, Judge El Araby's concurring opinion, July 9, 2004, para 3.1). The "most conspicuous consequence" of a crime reaching jus cogens status is that it cannot be derogated from by states, either "through international treaties or local or special customs or even general customary rules not endowed with the same normative force (Prosecutor v Furundzija, case no IT-95-17/1-T, judgment, Trial Chamber, December 10, 1998 ("Furundzija decision"), para 153)."

Although some scholars claim that there should be no hierarchy of human rights atrocities, it is generally accepted that this "core" of rights has a special status such that they should be prohibited at all times - see Jo M Pasqualucci, "The Whole Truth and Nothing but the Truth: Truth Commissions, Impunity and the Inter-American Human Rights System", 12 Boston University International Law Journal 321 ("Pasqualucci"), p 334. As the International Criminal Tribunal for the Former Yugoslavia ("ICTY") stated in the Furundzija decision, paras 153-54:

"[b]ecause of the importance of the values it protects, this principle has evolved into a peremptory norm or jus cogens, that is, a norm that enjoys a higher rank in the international hierarchy than treaty law and even 'ordinary' customary rules."

Precisely which rules are jus cogens or how a rule reaches that status is not clearly defined; however, it is generally accepted that jus cogens crimes include genocide, aggression, crimes against humanity, war crimes, piracy, slavery (and slave-related practices) and torture. Sufficient legal basis exists to reach the conclusion that all these crimes are jus cogens (see M Cherif Bassiouni, "International Crimes: Jus cogens and obligation erga omnes", Law and Contemporary Problems, vol 59(4) ("Bassiouni"), p 68). The Statutes of the ICTY and ICTR address genocide, crimes against humanity, and war crimes. The 1996 Code of Crimes Against Peace and Security of Mankind: Titles and Articles on the Draft Code of Crimes Against Peace and Security of Mankind adopted by the International Law Commission on its Forty-Eighth Session (1996) includes these three crimes in addition to the crime of aggression. These categories of crimes endlessly overlap: genocide, for example, is a crime in its own right as well as a crime against humanity and, during an armed conflict, a war crime. A war crime includes behaviour which, in peace time, could be classified as a crime against humanity.

As elaborated below, the non-derogability of certain international crimes, deriving from their jus cogens status, serves as a basis for arguing that these types of crimes may not be pardoned or amnestied. The recognition of an international crime as jus cogens carries with it the duty to prosecute and punish, the non-applicability of statutes of limitation for such crimes, and universality of jurisdiction over such crimes irrespective of where they were committed, by whom, against what category of victims, and irrespective of the context of their occurrence (peace or war). Bassiouni states (at p 66): "Above all, the characterisation of certain crimes as jus cogens places upon states the obligation... not to grant impunity to the violators of such crimes." 
The inconsistency of amnesties and pardons with obligations of states

Certain types of amnesty are universally condemned. For example, "self-amnesties" promulgated by persons or regimes while they are still in power, purporting to protect themselves from prosecution once they relinquish power, are considered to be "an affront to the rule of law and to the principle that [no one] should benefit from one's own bad faith" (Alice H Henkin, Conference Report, in Justice and Society Program of the Aspen Institute, State Crimes: Punishment or Pardon, Paper and Reports of a Conference (1989), p 4 in Pasqualucci). In general, however, states, pursuant to the doctrine of national sovereignty, are free to pass amnesty and pardon laws as they please. The legality of such action aside, a state may nonetheless limit its sovereignty by ratifying an international treaty which has non-derogable obligations.

For an amnesty or pardon to be legitimate under international law, it must not contravene a state's obligation under any human rights treaty to which it is a party. The SCSL recognised in the Gbao case that, in international law, states have a duty to prosecute crimes whose prohibition has attained the status of jus cogens. Therefore, the grant of amnesty or pardon for genocide, crimes against humanity or war crimes would be a breach of a state's obligations under international law, or at the very least inconsistent with its duty, to provide accountability for and prosecute these crimes. Article 4 of the Genocide Convention stipulates that persons who commit genocide shall be punished, whether they are constitutionally responsible rulers, public officials or private individuals. Article 5 requires contracting parties to act affirmatively by enacting legislation providing effective penalties for persons guilty of genocide. Treaty obligations under the Genocide Convention, being jus cogens, cannot be excused and the Vienna Convention on the Law of the Treaties states in article 26 that a state party "may not invoke the provisions of its internal law as justification for its failure to perform [its obligations under this Convention]". The same argument can be applied with respect to domestic obligations to prosecute and punish under the Geneva Conventions, the Convention against Torture, etc.

The assertion that any amnesty given for jus cogens crimes is inconsistent with the duty of states to provide accountability for those crimes is consistent with international and regional jurisprudence, as a number of cases including the Kallon decision and the Furundzija decision have held. The United Nations Human Rights Committee, the Inter-American Court of Human Rights and the Inter-American Commission on Human Rights have all concluded that amnesty laws and other similar domestic measures are generally incompatible with a state's obligations under international law. The ICTY and the SCSL likewise have issued decisions supporting this position, their conclusions based largely on a state's obligations, as established in various human rights instruments, to prosecute and punish the perpetrators of serious international crimes (eg Furundzija, Kallon and Kondewa decisions). The Human Rights Committee has ruled (General Comment No 20 (on art 7), 44th session (1992)) that amnesties granted for torture "are generally incompatible with the duty of states to investigate such acts; to guarantee prosecution of such acts within their jurisdiction; and to ensure that they do not occur in the future." This is consistent with the position favoured by the Inter-American Commission, in the context of its dealings with amnesty laws in South American countries, which has condemned such laws as being contrary to the obligation of states to investigate and punish human rights violations.

\section{Amnesties and pardons for jus cogens crimes are impermissible in international law}

Domestic amnesties, regardless of their legality under domestic law, cannot immunise a perpetrator being charged with, or prosecuted for, serious international crimes before an international court. Following from the recognition of the inconsistency of amnesties with international law obligations, there is a substantial body of cases, comments and rulings which deny the permissibility of amnesties in international law for jus cogens crimes. In the Barrios Altos Case, 2001 Inter-American Court of Human Rights (ser C) No 75, the government of Peru was brought before the InterAmerican Court of Human Rights regarding an amnesty law it enacted to exonerate persons who had violated human rights over a 15-year period. The court held that:

\section{"All amnesty provisions [...] are inadmissible, because they are intended to prevent the investigation and punishment of those responsible for serious human rights violations such as torture $[. .$.$] execution and forced disappearance, all of them$ prohibited because they violate non-derogable rights recognised by international human rights law."}

In the Furundzija decision, the Trial Chamber of the ICTY ruled that because of the jus cogens value of serious international crimes, treaties or customary rules which authorise or otherwise provide for amnesties for those crimes are null and void. Therefore, it would be "senseless to argue" that a state could take national measures authorising or condoning such crimes or absolving its perpetrators through an amnesty or pardon law. If such a situation were to arise, those national measures and any relevant treaty provisions "would not be accorded international legal recognition". Not only was the prohibition on torture jus cogens, but any amnesty for this crime would be inconsistent with international law and would, therefore, not hinder prosecution before the ICTY.

The SCSL has also ruled that despite the lawfulness of an amnesty in respect of a jus cogens crime/s, it could exercise its jurisdiction to attribute no weight to an amnesty that was granted contrary to the evolving principles of international law and to "obligations under certain treaties and conventions the purpose of which is to 
protect humanity." In the Kallon decision, the SCSL considered the appeals of two defendants who argued that the amnesty granted under the Lome Agreement precluded their trial before the SCSL. The Lome Agreement was a ceasefire agreement between the Sierra Leone government and the main rebel faction. The intention of the parties was that this amnesty would cover all crimes committed by combatants on either side of the conflict, which allegedly included acts of mass mutilation, mass murder and some of the most egregious crimes ever seen. There was to be an "absolute and free pardon" for all combatants and collaborators who were to suffer "no official or judicial action" for anything done in the pursuit of their objectives. A note was added to the agreement to the effect that "the United Nations interprets that the amnesty shall not apply to international crimes of genocide, crimes against humanity, war crimes and other serious violations of international law". This did not accord with the intention of the parties who signed the agreement (other than, perhaps, the UN special representative).

The SCSL, holding that the amnesty was ineffective, stated in the Kallon decision that it is:

"unrealistic to regard as universally effective the grant of amnesty by a State in regard to grave international crimes in which there exists universal jurisdiction. A State cannot bring into oblivion and forgetfulness a crime, such as a crime against international law, which other States are entitled to keep alive and remember."

\section{The special case of the hybrid tribunals}

The international jurisprudence makes clear that domestic amnesties, regardless of their legality under law of the state granting them, cannot immunise a perpetrator from being prosecuted for serious international crimes by an international court. The decisions of the ICJ and the SCSL, as well as many national courts, note that international law is autonomous from domestic law. However, with respect to prosecution of these crimes under a domestic court, different issues arise, including the question of which law to apply. This issue came up in the Ieng Sary case, given that the KRT is a mixed court with a preponderantly national character. The model of the KRT, being a special "hybrid" tribunal which is statutorily constituted to apply both national and international laws, poses interesting challenges in relation to the question of which (potentially conflicting) laws and principles to apply.

Given the KRT's unique hybrid characteristics, it could be argued that the decisions of purely international tribunals, such as the ad hoc ICTR and ICTY, do not directly apply. However, although the KRT was established within the existing structure of the Cambodian courts, it is still subject to specific rules and procedures, is not part of the hierarchy of the Cambodian judiciary and possesses sufficient international attributes that the reasoning of the decisions of international tribunals remains persuasive (see
Case of Kaing Guek Eav, Case File No 001/18-07-2007ECCC/OCIJ (PTC 01), Decision on Appeal Against Provisional Detention Order of Kaing Guek Eav alias "Duch", December 3, 2007, paras 18-20). When the United Nations and the Government of Cambodia signed the agreement to create the KRT, they decided that "where there is a question regarding the consistency of [a rule of Cambodian law] with international standards, guidance may $[\ldots]$ be sought in procedural rules established at the international level." The KRT Law also demands that the tribunal exercise its jurisdiction in accordance with "international standards" flowing from Cambodia's obligations under the ICCPR, to which it is a party. Such international standards necessarily flow from the law and procedure developed through international and internationalised tribunals dealing with similar crimes of mass atrocity as are being tried at the KRT, such as the ICTY and ICTR, the SCSL (which is also a "hybrid" tribunal, although not part of the national judicial system) and the International Criminal Court.

\section{Amnesties for jus cogens crimes unacceptable in domestic courts}

Even if the KRT was characterised as a purely national court this would not necessarily preclude it from rejecting Ieng Sary's pardon based on international law principles. Generally, every state, being an independent sovereign entity, may apply its own laws to a situation — unless there is some rule prohibiting it from doing so. To the extent that a court is using universal jurisdiction as the basis to try an offender, it has a dual role: to apply and interpret national law, and to effectively also sit as a court of the international community, applying international legal rules.

Where international law obliges a state to prosecute and punish those guilty of international crimes, this obligation extends to national courts as organs of the state. To the extent that an amnesty or pardon is incompatible with the international obligations of a state, a national court is bound to hold that amnesty or pardon violates internationally protected human rights (Report of the International Law Commission on the work of its fortyeighth session, May 6 to July 26, 1996, United Nations document, Supplement No 10 (A/51/10), p 6); state practice supports international jurisprudence on this point: national courts have annulled several domestic amnesties granted to military and political leaders suspected of international crimes as violating international law, based on the supremacy of international law in the domestic constitutional order, the incompatibility of domestic legislation with international treaty law and the fact that the crime involved a violation of a jus cogens norm.

The case law to date fairly consistently concludes that amnesties cannot "travel" to other jurisdictions, particularly the jurisdictions of international courts and tribunals. states, not legally bound by an amnesty granted by another state, may take universal jurisdiction to try a 
genocidaire who comes within their borders (see the Kallon decision, para 69). The jus cogens character of crimes, the House of Lords held in $R_{v}$ Bow Street Magistrate, ex parte Pinochet (No 3) [1998] 2 All ER 97 ("Pinochet"), justifies states taking universal jurisdiction over such crimes wherever committed. The principle of universal jurisdiction ? whereby states can claim universal jurisdiction over persons whose alleged crimes were committed outside the boundaries of the prosecuting state ? is justified on the grounds that the crime committed is considered to be a crime against all of humanity, which any state (and certain international tribunals) is authorised to punish. As the House of Lords stated, jus cogens offences may be punished by any state, as well as by the international community as a whole, because the offenders are "common enemies of mankind and all nations have an equal interest in their apprehension and prosecution" (Pinochet, pp 108-9, quoting Demjanjuk v Petrovsky (1985) 603 F Supp 1468).

Where jurisdiction is universal, a state cannot deprive another state (or an international tribunal) of its jurisdiction to prosecute the offender by granting an amnesty. Given that states possess universal jurisdiction to try jus cogens crimes, this jurisdiction may arguably be invoked by a domestic court to override an amnesty or pardon given for those crimes. Being non-derogable, jus cogens crimes may not be set aside by conflicting laws ? international, regional or domestic. International criminal law norms are, and have been since at least the Nuremberg trials, norms that may prime national laws and render them inoperative under certain conditions. The Charter and the judgment of the International Military Tribunal at Nuremberg clearly affirmed the primacy of international law over national law at least insofar as crimes against peace, war crimes and crimes against humanity were concerned. The Nuremberg Principles were adopted in a resolution by the United Nations General Assembly in 1946 and have not been seriously questioned since. It would seem odd for international law to prime national law, only for national law to be able to extinguish international law obligations through the application of a statute of limitations, amnesty, pardon or some other form of domestic immunity. This would be contrary to the foundational principles of international criminal law, and stand in opposition to the clear weight of authority and much of the state and international practice emerging in the field.

\section{CONCLUSION}

The Pre-Trial Chamber of the KRT concluded in the Ieng Sary case, somewhat unsatisfactorily, that "the validity of the amnesty is uncertain" and it is "not manifest or evident" that the amnesty and pardon will prevent Ieng Sary being convicted of genocide before the KRT. Therefore, the case against Ieng Sary was permitted to continue, with the issue likely to be raised again before the KRT's Trial Chamber during Ieng Sary's substantive trial, which has yet to begin.

Despite the current uncertainty regarding the applicability of Ieng Sary's pardon at the KRT, there is a substantial body of case law and commentary which denies the permissibility of amnesties in international law for genocide, crimes against humanity and war crimes. While recent decisions do not go so far as to declare amnesties or pardons illegal, there appears to be a general consensus, and an emerging rule of customary international law, against allowing amnesties and pardons effectively to immunise the perpetrators of jus cogens crimes.

\section{Anees Ahmed}

International Senior Assistant Prosecutor at the Extraordinary Chambers in the Courts of Cambodia ("ECCC"). He was an IALS Visiting Fellow during January-March 2008.

\section{Merryn Quayle}

Solicitor, admitted in New South Wales, currently interning at the ECCC. ECCC, popularly known as the Khmer Rouge Tribunal ("KRT"), is a hybrid criminal tribunal comprising of national (Cambodian) and international officials.

The authors represent the international component of this tribunal, ie the United Nations Assistance to the Khmer Rouge Trials ("UNAKRT”). The views expressed in this paper are solely those of the authors and do not necessarily represent the views of the KRT or the United Nations. The authors can be reached at aneesahmed97@gmail.com and merryn.quayle@freehills.com respectively. 